\begin{tabular}{c} 
Volume and Issues Obtainable at Center for Sustainability Research and Consultancy \\
Sustainable Business and Society in Emerging Economies \\
ISSN: $2708-2172$ \& (E): 2708-2504 \\
Volume 3: Issue 2 June 2021 \\
CSRE \\
Journal homepage: $\underline{\text { www.publishing.globalcsrc.org/sbsee }}$ \\
\hline
\end{tabular}

\title{
Accessing Foreign Aid's Long Run Contribution to Economic Growth of Pakistan: An Evidence from Time Series Data
}

*Hina Ali, Department of Economics, The Women University Multan, Pakistan.

Javeria Masood, Bahauddin Zakariya University, Multan, Pakistan. Afifa Sadar Ud Din, Department of Economics, The Women University Multan, Pakistan

*Corresponding author's email address: hinaali@wum.edu.pk

\begin{tabular}{l}
\hline ARTICLE DETAILS \\
\hline History \\
Revised format: May 2021 \\
Available Online: Jun 2021
\end{tabular}

Keywords

Population Growth,

Foreign Aid,

Inflation,

Foreign Direct Investment, Gross Domestic Product

\section{JEL Classification}

F35, F43,E31, E44

\section{ABSTRACT}

Purpose: This research examines the effectiveness of foreign aid on Pakistan's economic growth. The foreign aid efficiency is still under question. Some researches show positive affiliation of foreign aid with economic growth while some show negative affiliation. If foreign aid is not replacing or used as a substitute for domestic savings then foreign aid is useful for growth. To fill the two gaps of the economy the Two-Gap theory suggest that poor nations have to depend on overseas funds. Those two gaps are the Savings-Investment Gap and Import-Export Gap. There're many kinds of international funds. Like foreign loans, development and non-development aid, FDI, and technological help. But underdeveloped nations like Pakistan have not a favorable speculation policy. Therefore, these nations are dependent on international aid and balance quite than foreign direct investment.

Design/Methodology/Approach: For the analysis of this study the time era used is 1974 to 2016. The GDP is the dependent variable. Independent variables are population growth, foreign aid, inflation, foreign direct investment (FDI), and domestic savings. The annual data is collected from different sources. The technique for analysis is OLS and ARDL bound testing.

Findings: Concluding remarks show that in Pakistan foreign aid affects economic growth negatively.

Implications/Originality/Value: The current study was based on the least considered variables and the pioneer in testing the complex relationship through OLS and ARDL estimation.

\section{OPEN ACCESS}

(C) 2021 The authors, under a Creative Commons AttributionNonCommercial- 4.0

Recommended citation: Ali, H., Masood, J. and Din, A. S. (2021). Accessing Foreign Aid's Long Run Contribution to Economic Growth of Pakistan: An Evidence from Time Series Data. Sustainable Business and Society in Emerging Economies, 3 (2), 83-94

\section{Introduction}

Foreign aid is good or bad for economic growth. The effectiveness of foreign aid is still under question. After World War II many countries, especially underdeveloped countries highly appreciate stimulating 
outdoor support or foreign aid to boost investment or output growth. But in under developing countries or poor countries, foreign aid has a positive effect, as well as negative effects, show on economic growth at the same time. Foreign aid is useful for growth if it does not replace domestic savings. Foreign aid can be clear as the financial, mechanical, and military assistance given by one nation to another for the reason of help and cure, financial stabilization, or for mutual protection. External assistance or foreign aid has multiple forms such as grants, foreign private assistance, developmental loans, and official loans, tied and united loans. Bilateral and multilateral loans and many others.

Foreign aid to Pakistan includes many types of aids these are (a) support Project (b) Commodity aid (c) for food Aid under PL 480 and (d) Technical support. The huge amount of foreign assistance that Pakistan received has been in the type of fixed project aid in the majority of the cases for both resource and use. Development assistance is a sort of assistance that is earmarked on behalf of special advance initiatives, such as irrigation schemes and huge manufacturing networks and communications introduced a significant component. The second-largest factor of the assistance received by Pakistan is commodity support. This type of aid is allowed a certain degree of flexibility. Land use is not fixed, but in most cases, it is linked to sources. (Khuhro et al., 2012, March).

This is the reason that the Pakistan Commodity support elected rather than aid projects. Commodity aid whiles a proportion of the entire aid falls34\% in 1960-1965 to 23\% in 1979-1980. The third huge factor of aid to Pakistan is Food aid less than PL 480. These aids provide by the United States through the sale of surplus agriculture products. The funds from the trade of these remaining farming products are then paid complement support prohibited by the US management throughout relieve job to Pakistan. Distribution of the resources, defined as help, among other actions the maintenance of the US Government. The fourth type of foreign aid is vital for Pakistan, for the reason that Pakistan is lacking technological awareness, capitalist capacity, and expert labor. (Abbas \& Raza 2013).

Two-Gap Model and Foreign Aid: Hollis Chenery and A. Strout were present in this model. According to them most of the developing countries face the two-gap model. These Two Gaps are: (1): The lack of domestic (national) savings to cope with the Investment opportunities. (2): The lack of financing foreign currency needed for imports of intermediate goods \& capital. These two, Savings and Foreign exchange gaps are traditional "TWO-GAP". According to this model, to achieve self-sustained growth a country passes through three stages: First, absorption is a withdrawn economy that cans useful investing the minimum amount.

Purpose of foreign assistance, to increases this stage to the recording capacity of the economy, via providing technical help, proper education, and guidance, and so on. Foreign aid is a contentious matter. Some community says that it increases economic growth or some argue that it increases the debt burden. Here its main benefits or importance are as follows: Increased production: The influx of aid as capital or technology to increases production in various sectors of the economy. Increases investment level: In less developed economies, such as Pakistan, the saving rate is low. We cannot meet the needs of investors. International aid or loans can fill this gap. It increases the rate of investment. For the Trade deficit: Less developed countries face the deficit BOP. So this deficit is filled with the help of foreign aid. Increase employment level: With the assistance will be determined by the development of foreign aid plan different or new industries. So we will employ new workers. It raises the employment level in the country. Increase in real wages: Inflow of capital will increase the output level. Foreign aid increases the competence of the workers. Thus it increases the real wages of their marginal product. (Nkoro, \& Furo 2012).

An increase in government revenue: The profit which ears by the foreign investment will tax by the government. New projects of foreign investors raised revenue. In this way the revenue of the government raises. Outdoor economies: With the flow of overseas aid, enterprises can enjoy the benefits of external economies such as the formation of labor and the beginning of new machinery. Improved 
quality of production: Foreign aid generates new industries in the economy. The influx of capital and technology advances the worth of manufacture and lessens cost. Rate of development increases: The correct use of external aid can be useful in developing countries and increasing development in these countries. Make love and brotherhood: Foreign assistance generates love and brotherhood between wealthy and deprived nations because aid makes the poor nation wealthy. (Mohey-ud-din, 2005).

Beyond the importance or benefits of foreign assistance, there are also disadvantages of foreign assistance because several citizens squabble that the capital is not a single factor in increasing economic growth or development rate in a country. These are: (1): Increase in the burden of debt, (2): Payment of interest, (3): dangerous for freedom, (4): Tied loans, (5): Foreign dependence, (6): Cause of inflation, (7): Aims of aid givers, (8): External Indebtedness, (9): Projects not requiring aid, (10): Uncertainty, (11): Misuse of aid, (12): Economic sovereignty. Similar to many other less developed economies, Pakistan relies on foreign aid to finance to increase national savings investment. To bridge the gap of resources, it starts external debt in the 1950s. Over the years, there was a stop begging off the inflow of aid to Pakistan. Just transfer is made as regards $90 \%$ of unpleasant expenditure in 1964-1965 was fall to $56 \%$ in $1977-1978$ and $50 \%$ in $1979-1980$.

In starting years received a high percentage of aid as a grant or aid assistance. Such assistance was reduced and changed by the term of foreign grants and credits are repayable in foreign currency with the terms \& conditions strictly. In the first plan, the share of aid or assistance in total commitments was $80 \%$. This $80 \%$ share was reduced to $46 \%$ on the second floor and $31 \%$ reduced during the 3rd floor. It has $12 \%$ in the period of non-plan. Moreover, the share of aid is increased slowly by over $20 \%$ during the five years of the plan. From 2002 to 2009 only $30 \%$ of foreign aid was used in economic-related needs. The remaining $70 \%$ allocated to security-related assistance. From 2010 to 2016 only $41 \%$ of aid is used in economic needs.

Figure 1: Trend of dependent and independent variables

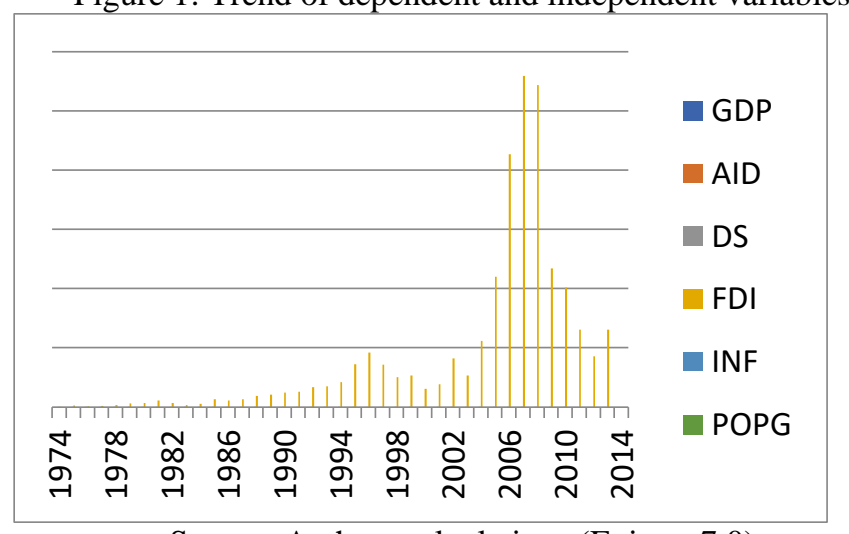

Source: Authors calculations (Eviews 7.0)

Figure 1 shows the 40 years trends of foreign assistance's effect on economic growth in Pakistan. According to the economic survey of Pakistan in 1974, GDP has a 132.58 percent rate in Pakistan and then increased and fluctuate year by year.

\section{Literature Review}

Din (2005) examined the contact of foreign support for financial development in Pakistan (1960-2002). This study analyzed the trend and performance of international aid and the effectiveness or role in the Pakistan economy. The study describes two variables are the growth of GDP and the Debt burden. The source of the data calculated at stable prices of 2000. For the analysis, the quadratic regression model is used. The study concludes empirically both negative and positive effects of foreign assistance. So the overall effect of foreign aid is positive on economic growth. But replacing the detriment of the aid equal to domestic savings has increases the debt burden. The policy has played a role ineffectiveness of 
foreign aid. The assistance perhaps useful for a financial expansion increased simply with the existence of the monetary policy, fiscal, and trade policies.

Khan and Ahmad (2007) examined that Foreign Aid is good or bad: facts from Pakistan. This study investigates whether international support is a lucky thing or bothers for Pakistan. The variables of this study are economic growth, foreign aid, export, domestic investment, and FDI. This study examines the link between aid growth in total and disaggregated levels for the era of 1972 to 2006. The analytical study is based on an approach of cointegration ARDL. In the end, results showed the negative effect of overseas aid on augmentation in total and a broken face. The study also suggests that inward investment, growth of export, and the inflows of foreign direct investment strengthen major providers to financial enlargement in Pakistan.

Shehzad et al. (2011) examined the effect of international assistance on government spending in the case of Pakistan. The total expenditures of government, actual government spending for development, total domestic resources, the program aid, and project aid are taking as a variable in this study. The data period is 1990-2008. The sources of the data are the Pakistan economic survey, some official publications, and WDI reports. To analyze, the data study uses a Simple regression model. The research concluded that there is a positive association between the two programs and project assistance and government expenditure.

Min and Sanidas (2011) analyzed the impact of the support of Foreign Functional classes for economic development in receiver economies. The research suggested that there are three important visits to the efficiency of overseas funds. Firstly, international support was seen as direct in terms of the impact on expansion. Secondly, foreign support is effective while assured circumstances are met. Thirdly, aid doesn't have significantly positive returns, not on economic growth. To explain all these aspects are examined seven major functional forms of support. This study takes the variables are index of Physical Quality of Life, HDI, dependency ratio of age, infant mortality rate, the rate of adult literacy, and GDP growth. The entire variables are used in the analysis as dependent variables to evaluate the efficiency of the aid. The study used a range of them for the prose and the 7 sorts of assistance, these are independent variables. At the end of the investigation, all types of assistance become conditional variables in diverse customs. This study used panel figures procedure, as permanent effects, arbitrary effects, and the organization GMM. Finally, the study verifies the optimistic force of foreign assistance for financial development.

Chowdhury and Das (2011) examined the link Aid expansion in south Asia: facts as of the time series and panel cointegration. This study investigates the connection between overseas help and real GDP as per capita is relatively uncertain. This means aid doing work in South Asia? For five nations in this district, study analysis: Bangladesh, Pakistan, India, Nepal, and Sri Lanka. The research evaluates four key variables, per capita real GDP, foreign assistance as a fraction of GDP, nasty wealth formation as a fraction of GDP, and trade Openness as a proportion of GDP. The yearly data is used for the period 1976 to 2008. All this data will be taken respectively, from WDI, International Financial information record, and OECD reports, and International Monetary Fund. For the analysis, the study uses both sets of nation-explicit time series plus a procedure of co-integration. The result of the study demonstrates a helpful time-consuming association connecting the development speed of real GDP for each capita and support as a fraction of GDP for 4 beyond 5 countries. In the end, these investigations tend to hold the hypothesis's effectiveness of aid for the South Asian countries.

Fatima et al. (2012) investigate the contact of the inflow of domestic resources and foreign capital for Pakistan's economic growth. The time used is from 1975 to 2008. This study takes the economic growth as needy variable and FDI, overseas aid; national resources are as autonomous variables. This study was analyzed by multiple linear regressions service ordinary least square method (OLS). The consequences of this study break down that FDI has a statistically encouraging relation plus momentous role to the 
economic extension in this country. But, international assistance has an insignificant effect on financial growth and national resources have been found to contribute more to the rate of economic growth, compared to accelerate foreign resources. In the end, the study suggested that the reliance on foreign aid must cease or be used only for productive purposes.

Jones (2013) tested the hypothesis growth driven foreign assistance in the West African economies. This study evaluates the growth assumptions in foreign aid led by a group of West African countries. Total 16 th countries in West Africa were used in the sample. The International Financial Statistics database of the International Monetary Fund and African bank by Economic indicators, and from the Social Data Service reports, time-series data utilized for empirical investigation. The variables taken by this study are Real GDP, labor, stock of domestic resources, international aid, FDI, and official development assistance. This study uses panel co-integration techniques and then on a country to the country origin, by the use of cointegration methods of time series. The study concludes that the cointegration fellow panel shows a lengthy relation among support and development in the entire panel. In the end, the study shows evidence of causality check of overseas aid for economic development.

Bashir et al., (2016) investigated the flow of foreign capital and the economic development of Pakistan. This research takes growth as a dependent while external debt servicing, FDI, workers' remittances, national investment, rate of inflation measured by GDP deflator plus the literacy rate are the independent variables. The sample period taken is 1972-2013. The cointegration test of Johansen and the causality test of the granger were used for data analysis. This study shows the negative effects of the flows of the economic growth of the economy in the long term. Analysis of the short period victims checks debt service in the form of running, FDI, inflation, and rate of growth literacy. Bidirectional casualty shows between remittances and growth.

\section{Data and Research Methodology}

In this segment, the researcher briefly outlines the data methodology and empirical setup via illustrating data and by examining structural and statically approach to estimate the relation of foreign assistance with economic growth in Pakistan.

\section{Data}

This research uses the secondary type of figures. The data series covered the period from 1974 to 2013. The data series examined in this research is collected from secondary data sources. Secondary data sources of this study are world development, the World Bank (WB), Pakistan Economic Surveys, and Hand BOOK of statics (SBP or State Bank of Pakistan).

\section{Variables Description:}

The quantitative variables are used in the analysis for examining the relationships between foreign aid and economic growth. Following is the table showing variables used in this research;

Table 1: Description of variables

\begin{tabular}{ccccc}
\hline Variables & $\begin{array}{c}\text { Description of } \\
\text { variables }\end{array}$ & Unit & Expected sign & Source \\
\hline GDP & $\begin{array}{c}\text { Gross domestic } \\
\text { production }\end{array}$ & In current dollars (US\$) & +ve sign & World development indicator \\
POPG & Population Growth & In annual percent (\%) & -ve sign & World development indicator \\
AID & Foreign Aid & In percent (\%) & -ve sign & World development indicator \\
INF & Inflation & In annual percent (\%) & -ve sign & World development indicator \\
FDI & Foreign direct & In current dollars (US\$) & +ve sign & World development indicator \\
& investment & In price rupees & -ve sign & Economic Survey of Pakistan \\
\hline DS & Domestic saving & & Source: author's calculation &
\end{tabular}

The table shows all variables that are utilized in this research. This table also displays the units of 
measurement and their expected sign of these variables. The dependent variable of this research is gross domestic product (GDP, in USS dollar). While, Independent variables are population growth, foreign aid, inflation, foreign direct investment, and domestic savings.

The dependent variable GDP has an expected positive significant sign. Independent variables are population growth, aid, inflation, and domestic savings. Population growth (POPG) has an expected negative significant impact. AID has also a negative significant impact. Inflation (INF) has an expected negative significant sign. Domestic saving (DS) has an expected positive significant impact. In the last column, the data source is mentioned.

\section{Methodology}

The OLS (ordinary least square) and ARDL (Auto-regressive distributed lagged model) are the main statistical estimation techniques applied to measure the association among dependent (GDP) and independent variables (POP.G, AID, POP, DS, INF, and FDI) in the regression analysis. The OLS method is a much admired and generally used method examined by many researchers. Firstly, this technique was developed by Cart Friedrich Gausses in 1821.

\section{Model specification}

In the regression analysis mostly the model is used as follow:

$Y=a 0+b 1 X 1+b 2 X 2+B 3 X 3+e \ldots \ldots \ldots \ldots \ldots \ldots \ldots \ldots \ldots \ldots \ldots \ldots(1)$

In this model:

- $Y=$ dependent or needy variable

- $\mathrm{X} 1, \mathrm{X} 2$, and X3 are free or independent variables

This paper examined model that shows the association among the Foreign aid and economic growth is discussed below:

$\mathrm{Y}(\mathrm{GDP})=\mathrm{a} 0+\mathrm{b} 1(\mathrm{POPG})+\mathrm{b} 2(\mathrm{AID})+\mathrm{b} 3(\mathrm{INF})+\mathrm{b} 4(\mathrm{FDI})+\mathrm{b} 5(\mathrm{DS})+\mathrm{e} . . . . . . . . . . . .(2)$

In this model;

- $\mathrm{GDP}=$ Gross domestic product

- $\mathrm{POPG}=$ population growth

- $\quad \mathrm{AID}=$ Foreign assistance or aid

- $\mathrm{INF}=$ Inflation

- $\mathrm{FDI}=$ foreign direct investment

- $\mathrm{DS}=$ Domestic saving

- $\mathrm{e}=$ error term

\section{Gross Domestic Product}

The gross domestic product (GDP) is a quantitative measure of the broader economic activity of the country. GDP is the monetary cost of all goods and services produced within the borders of nation services during a specified period.

\section{AID}

In this paper, aid is used as foreign assistance or help. Foreign assistance can be distinct as economic aid, technological help, or military support from one country to another for the principle of release plus rehabilitation, financial stabilization, or communal security.

\section{Composition of Foreign Aid in Pakistan:}

International assistance to this country generally circulated in two main categories, namely assistance to the project and no aid project, while the aid is not to project is divided into; food assistance, non-food, BOP. The figure provides the division of foreign help to Pakistan. The part of project support stay high throughout the era $1952-1953$ to $2002-2003$ is $58 \%$, whereas the allocation of food, non-food, and BOP and support respectively are $10,11,18$, and 3 percent. 
Figure:2 The allocation of the entire Aid throughout (1952 to 2002)

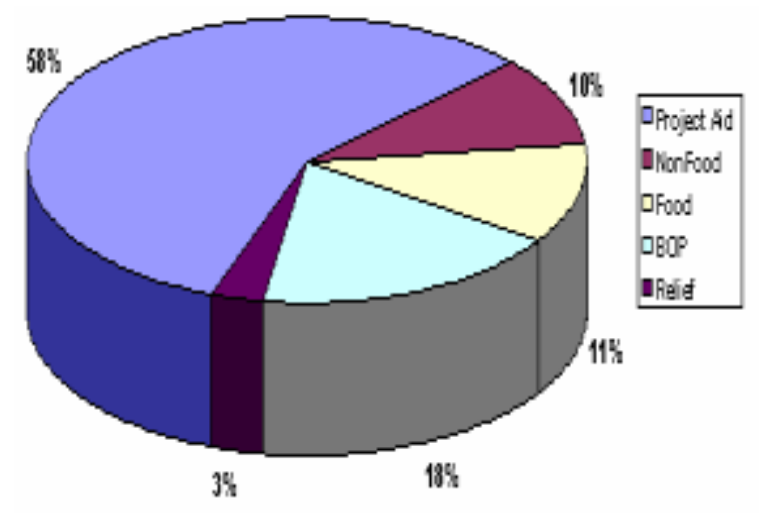

Source: Pakistan Government, Statistically Supplement: Pakistan economic survey (2002-03)

\section{Analysis and result}

In this segment, the researcher demonstrates the statistical estimations and interpretations. In this section, the researcher displays a descriptive statistics table, correlation matrix, OLS estimates, ARDL short and long run estimation, and CUSUM stability analysis.

\begin{tabular}{ccccccc}
\multicolumn{7}{c}{ Table 2: Descriptive Statistics } \\
\hline Variables & Mean & St. Dev. & Skewness & Kurtosis & J.B. & Prob \\
\hline GDP & 520.9812 & 307.2327 & 1.1891 & 3.3546 & 9.6372 & 0.0080 \\
POPG & 2.6031 & 0.6253 & -0.1979 & 1.5367 & 3.8294 & 0.1473 \\
AID & 2.4457 & 1.4003 & 1.5402 & 5.8359 & 29.2208 & 0.0000 \\
INF & 9.2982 & 4.9403 & 1.4950 & 5.8640 & 28.573 & 0.0001 \\
FDI & $8.68 \mathrm{E}+08$ & $1.37 \mathrm{E}+09$ & 2.4124 & 8.1320 & 82.6955 & 0.0000 \\
DS & 358649.2 & 459347.5 & 1.1399 & 2.8772 & 8.6890 & 0.0129 \\
\hline
\end{tabular}

Source: Author's calculation (Eviews)

The mean value shows the average value of all the variables. The standard deviation of GDP shows that its value is 307.23 units deviate from the actual value. In population growth its value is 0.62 units deviate from its actual value. The standard deviation of AID shows a 1.40 unit deviation from its actual value. Inflation shows a 4.94 unit deviation from an actual value. Foreign direct investment standard deviation shows the 1.37 units deviation and domestic savings are deviate at 459347.5 units from the actual value. The kurtosis values showed the variables are leptokurtic, mesokurtic, and platykurtic.

Foreign aids (AID), Inflation (INF), and foreign direct investment (FDI) have Leptokurtic distribution or at a high peaked. Gross domestic production (GDP) has a medium peaked or Messo-87Kurtic distribution. Other variables population growth (POPG) and Domestic savings (DS) have a low peaked or PlatyKurtic distribution.

The normality test of Jarque-Bera (JB) presents the joint result of skewness and kurtosis. The normality test of Jarque-Bera illustrates that the calculated 'prob' worth of Gross domestic production, foreign aid, inflation, foreign domestic investment, and domestic savings are zero. So it shows that they are not normally distributed. Population growth is normally distributed.

Table 3: Correlation Matrix

\begin{tabular}{ccccccc}
\hline & GDP & POPG & AID & INF & FDI & DS \\
\hline GDP & 1 & & & & & \\
POPG & -0.82624 & 1 & & & & \\
AID & -0.63168 & 0.54557 & 1 & & & \\
INF & 0.06108 & -0.05697 & 0.24716 & 1 & &
\end{tabular}




\begin{tabular}{ccccccc} 
FDI & 0.66556 & -0.63307 & -0.42520 & 0.19442 & 1 & \\
DS & 0.51869 & -0.720691 & -0.43891 & 0.00516 & 0.76751 & 1 \\
\hline
\end{tabular}

Source: Author's calculation (Eviews)

This table shows the correlation between the variables. The correlation between GDP and POPG is 0.826 and it shows multicollinearity. The correlation between GDP and AID is -0.631 and it shows no multicollinearity. The correlation between GDP and INF is 0.061 and it shows no multicollinearity. The correlation between GDP and FDI is 0.66 and it also shows no multicollinearity. The correlation between GDP and DS is 0.51 and it shows no multicollinearity. The correlation between POPG and AID is 0.54 and there is no multicollinearity. The correlation between POPG and INF is -0.05 and there is also no multicollinearity. The correlation between POPG and FDI is -0.63 and it shows no multicollinearity. The correlation between POPG and DS is -0.72 and it also shows no multicollinearity. The correlation between AID and INF is 0.24 and there is no multicollinearity. The correlation between AID and FDI is -0.42 and there is also no multicollinearity. The correlation between AID and DS is 0.43 and is shows no multicollinearity. The correlation between INF and FDI is 0.19 and it also shows no multicollinearity. The correlation between INF and DS is 0.005 and there is no multicollinearity problem. The correlation between FDI and DS is 0.76 and it shows no multicollinearity problem.

Table 4: OLS Estimates

\begin{tabular}{ccccc}
\hline Variable & Coefficient & St. Error & t-Statistic & Probability. \\
\hline C & 1643.984 & 162.8024 & 10.09803 & 0.0000 \\
POPG & -371.1809 & 55.65162 & -6.669723 & 0.0000 \\
AID & -50.92443 & 20.31020 & -2.507333 & 0.0171 \\
INF & -0.709922 & 5.015928 & -0.141534 & 0.8883 \\
FDI & $1.03 E-07$ & $2.72 \mathrm{E}-08$ & 3.797886 & 0.0006 \\
DS & -0.000321 & $8.68 \mathrm{E}-05$ & -3.700256 & 0.0008 \\
\hline R-squared & $\mathbf{0 . 8 2 6 8 2 2}$ & Mean dependent var & $\mathbf{5 2 0 . 9 8 1 2}$ \\
Adjusted R-squared & $\mathbf{0 . 8 0 1 3 5 4}$ & S.D. dependent var & $\mathbf{3 0 7 . 2 3 2 7}$ \\
S.E. of regression & $\mathbf{1 3 6 . 9 3 2 7}$ & Akaike info criterion & $\mathbf{1 2 . 8 1 4 3 4}$ \\
Sum squared resid & $\mathbf{6 3 7 5 1 8 . 8}$ & Schwarz criterion & $\mathbf{1 3 . 0 6 7 6 7}$ \\
Log likelihood & -250.2867 & F-statistic & 32.46588 \\
Durbin-Watson stat & 0.525850 & Prob(F-statistic) & 0.000000 \\
\hline
\end{tabular}

Source: Author's own calculation (Eviews)

This table illustrates the result of the specified model of regression analysis. It estimates the effect of foreign support for economic growth in Pakistan. 1 unit Change in population growth results is 371.1 units decrease in GDP and it shows the negative relation between GDP and POPG. The t-statics show that population growth is statistically momentous at a $1 \%$ level. The change in foreign aid results in a 50.92 unit decrease in economic growth and there is a negative relationship between economic growth and foreign aid. AID is statistically significant at 5\%. Inflation showed a negative relationship between economic growth and inflation. One unit change in the inflation result is 0.709 units fall in financial growth and insignificant. The change in foreign direct investment result is 1.03 units boost in economic expansion and is statistically significant at $1 \%$. It shows the positive relationship between GDP and FDI. Domestic savings shows a negative relation and the change in domestic savings is 0.00032 units decrease the economic growth. It is statistically considerable at a $1 \%$ level of significance. The result of the independent variables showed strong multicollinearity among independent variables. The high value of the F-static showed that the independent variables contained in the model collectively negatively related to Foreign aid and economic growth. The value of $\mathrm{R} 2=0.8268$ also adjusted $\mathrm{R} 2=0.8013$ are high i.e. excess of 0.80 that indicates the variability in the economic growth due to the independent variable is 80\%. Since population growth (POPG), foreign aid (AID), foreign direct investment (FDI), and domestic savings (DS) all have a negative significant impact at a $1 \%$ level of significance, Inflation (INF) has an insignificant impact on economic growth. 
Table 5: ARDL Estimation Table (Short Run)

\begin{tabular}{ccccc}
\hline Variable & Coefficient & Std. Error & t-Statistic & Prob. \\
\hline D(FDI) & -0.000000 & 0.000000 & -0.178325 & 0.8610 \\
D(FDI(-1)) & 0.000000 & 0.000000 & 2.023131 & 0.0626 \\
D(FDI(-2)) & 0.000000 & 0.000000 & 1.864095 & 0.0834 \\
D(FDI(-3)) & -0.000000 & 0.000000 & -3.599781 & 0.0029 \\
D(DS) & 0.000064 & 0.000056 & 1.139451 & 0.2736 \\
D(DS(-1)) & 0.000169 & 0.000062 & 2.717847 & 0.0167 \\
D(DS(-2)) & -0.000077 & 0.000121 & -0.637162 & 0.5343 \\
D(DS(-3)) & -0.000462 & 0.000161 & -2.877850 & 0.0122 \\
D(AID) & -14.800562 & 5.610528 & -2.637998 & 0.0195 \\
D(AID(-1)) & -4.484703 & 4.754598 & -0.943235 & 0.3616 \\
D(AID(-2)) & 8.038633 & 3.813696 & 2.107832 & 0.0536 \\
D(POPG) & -91.523280 & 252.576556 & -0.362359 & 0.7225 \\
D(POPG(-1)) & 641.385857 & 803.384624 & 0.798355 & 0.4380 \\
D(POPG(-2)) & -412.819628 & 320.940700 & -1.286280 & 0.2192 \\
D(INF) & 6.576490 & 1.798251 & 3.657159 & 0.0026 \\
CointEq(-1) & -0.818581 & 0.142061 & -5.762169 & 0.0000 \\
\hline
\end{tabular}

Cointeq = GDP - $(0.0000 *$ FDI + 0.0006*DS -26.9532*AID + 99.8885*POPG + $10.2365 *$ INF -2.1224$)$

Source: Author's calculation (Eviews)

In this table, the short run relationship between examined variables is exhibited. In the short run, the variable shows significant and insignificant results. The short run table does not clearly show the correct results therefore, we will look at the long run table. Here, in the short run, the value of CoinEq. is statistically significant. Significant cointegration equation value shows that there is the long run relationship between the examined variables of the study.

Table 6: ARDL Estimation Table (Long Run)

\begin{tabular}{ccccc}
\hline Variable & Coefficient & Std. Error & t-Statistic & Prob. \\
\hline FDI & 0.102300 & 0.000000 & 4.067691 & 0.0012 \\
DS & 0.000553 & 0.000108 & 5.107127 & 0.0002 \\
AID & -26.953157 & 8.420727 & -3.200811 & 0.0064 \\
POPG & 99.888525 & 40.855988 & 2.444893 & 0.0283 \\
INF & -10.236517 & 2.944421 & 3.476581 & 0.0037 \\
C & -2.122360 & 147.140655 & -0.014424 & 0.9887 \\
\hline \multicolumn{5}{c}{ Source: Author's own calculation (Eviews) }
\end{tabular}

In this table, the short run relationship between examined variables is exhibited. This table illustrates the result of the specified model of regression analysis. It estimates the effect of foreign support for economic growth in Pakistan. 1 unit Change in population growth results is 99.888 units increase in GDP and it shows the positive relationships among GDP and POPG. The t-statics show that population growth is statistically momentous at a 5\% level. The change in foreign aid results in a 26.953 unit decrease in economic growth and there is a negative relationship between economic growth and foreign aid. AID is statistically significant at $1 \%$. Inflation showed a negative relationship between economic growth and inflation. One unit change in the inflation result is 10.236 units fall in financial growth and significant. The change in foreign direct investment result is 0.1030 units boost in economic expansion and is statistically significant at $1 \%$. It shows the positive relationship between GDP and FDI. Domestic savings shows a positive relationship and the change in domestic savings is 0.0005 units decrease the economic growth. It is statistically considerable at a $1 \%$ level of significance. Overall, the results show that all variables of this are statistically significant. Moreover, except for foreign aid and inflation, all variables (population, FDI, and domestic savings) confirmed a positive relationship with GDP.

Table 7: ARDL Estimation Table (Bound Testing) Null Hypothesis: No long-run relationships exist 


\begin{tabular}{ccc}
\hline Significance & I0 Bound & I1 Bound \\
\hline $10 \%$ & 2.26 & 3.35 \\
$5 \%$ & 2.62 & 3.79 \\
$2.5 \%$ & 2.96 & 4.18 \\
$1 \%$ & 3.41 & 4.68 \\
\hline
\end{tabular}

The F-statistics critical value is larger than lower (I0) and upper (I1) bound values. Therefore, we can say long run association exists between examined variables.
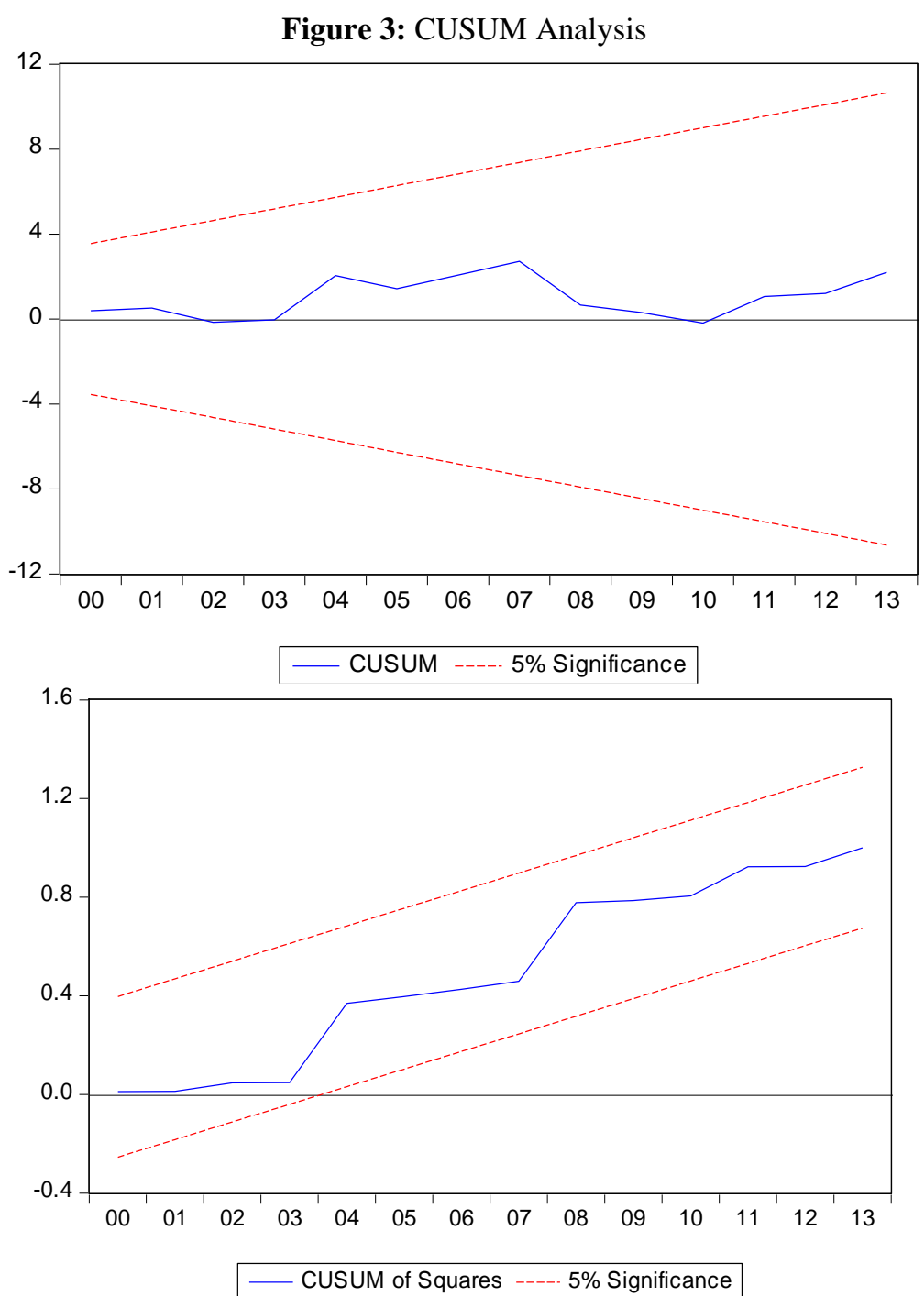

CUSUM graph and the CUSUM of the square graph show that examined model of this study is statistically significant.

\section{Summary and Conclusion}

The principal reason for this study is to determine the foreign aid effect on economic expansion in this country. This paper analyzed the relationship between GDP, foreign aid, population growth, inflation, FDI, and domestic savings. The basis for the empirical study of the belongings of foreign support began in 1960, with a general inspection that aid is useful for the growth and progress of countries in the developing world. But few economists dispute that international aid is not useful for all time to the developing countries, but it may be extra dependence on support, bribery, and financial mismanagement of the beneficiary countries cause. A large amount of empirical investigation about the relationship of aid/growth was carried out before; discover the positive relationships among them, at the same time few say this absolute relation depends on fine fiscal, monetary, and trade policies of nations. Also, a few 
types of research suggest there is no association among them or else negative.

Contained by the miscellaneous record of anticipate and worries, the paper empirically analyzed the effect of international assistance on economic development in Pakistan's economy during the era 19742013. Observed consequences point out an extremely small part of foreign support specified to the beneficial projects are successfully and professionally used, though the majority is wasted left. In this study, the analysis exhibits that aid is negatively connected with economic growth in Pakistan. In this paper, all the variables show a different relation with economic growth. Growth of population is also negatively related with the GDP when population increases growth of an economy automatically decreases due to the increase in population growth because increased population wants more sources and demand increases. The inflation rate is also negatively connected with economic growth when inflation increases in the economy then the GDP decreases because the increase in the prices decreases the growth of the economy. Inflation causes low savings and low investment. The foreign direct investment (FDI) shows an affirmative association with GDP when the foreign direct investment increases the new industries are developed then economic growth increases. Domestic saving displays a negative affiliation with GDP. When savings are higher than the investment then there will be a decrease in the growth of the economy. When savings are equal to investment the economy goes into development. All these variables are connected with foreign aid and confirm the negative effect of foreign support on financial growth. Aid appears, replaces domestic savings, increased the debt burden. Several indicators of debt of Pakistan have augmented with time and nation cultivated in serious problem credit service as the macro-economic organization, overseas trade policies, and national savings are not planned plus manufactured properly.

Consequently, there is not only want of superior policies, other than also the accomplishment of policies, also toward proper monitoring of aid projects that used, and it is necessary to prevent the negligence and mismanagement of international resources. Therefore we say that aid can use to raise financial growth only with the presence of suitable pecuniary, financial, and stimulate trade policies.

\section{Suggested policies:}

One guiding principle based on practical data of the paper is to augment the impact of overseas aid in the growth and development of Pakistan.

1: accountability for improved use of foreign support in development division depends on together contributor and receiver nations. The policy of contributors is alarmed, they ought to the receiver country to plan and originate the policies and venture.

2: in the recipient countries they should provide more resources for the development sector. More funds should be provided for the improvement of the technology or to improve the quality of products and their industries.

3: also, they must develop an arrangement of liability and precision to lessen any possibility of fungibility assistance into other divisions of receiver countries.

\section{References}

Abbas, M., \& Raza, H. (2013). Effects of the trade deficit on the economy of Pakistan. Interdisciplinary journal of contemporary research in business, 4(11), 176-215.

Bashir, T., Mansha, A., Zulfiqar, R., \& Riaz, R. (2016). Impact of FDI on economic growth: a comparison of the South Asian States \& China. European Scientific Journal, 10(1).

Chaudhry, I. S., Malik, S., \& Ramzan, M. (2009). Impact of foreign debt on savings and investment in Pakistan. Journal of Quality and Technology Management, 5(2), 101-115.

Chowdhury, M., \& Das, A. (2011). Aid-growth nexus in South Asia: evidence from time series and panel cointegration. Research in Applied Economics, 3(1), 1.

Fatima, S., Azeem, M. M., Elahi, E., \& Abid, M. (2012). Comparative analysis of foreign capital inflows and domestic resources in the economic growth of Pakistan. Journal of Agriculture and Social 
Sciences (Pakistan).

Jones, Y. M. (2013). Testing the foreign aid-led growth hypothesis in West Africa.

Khan, M. A., \& Ahmed, A. (2007). Foreign aid-blessing or curse: Evidence from Pakistan. The Pakistan Development Review, 215-240.

Min, K., \& Sanidas, E. (2011). The impact of Foreign Aid's 7 functional categories on economic development in recipient countries. Korea and the World Economy, 12(1), 117-179.

Mohey-ud-din, G. (2005). Impact of Foreign Aid on Economic Development in Pakistan [1960-2002].

Khuhro, T. N., Bhutto, N. A., Butt, F., Naz, M., Shah, W. A., \& Zarqa, S. (2012, March). Impact of foreign aid on income inequality. In The 2nd International Conference on Business Management. Lahore, Pakistan (pp. 28-29).

Nkoro, E., \& Furo, A. O. (2012). Foreign capital inflows and economic growth in Nigeria: An empirical approach. Academic Journal of Interdisciplinary Studies, 1(2), 55-55.

Shahzad, A., Ahmed, T., Khiliji, B. A., \& Ahmed, I. (2011). Impact of foreign aid on public expenditure in Pakistan. Researchers World, 2(3), 98. 